\section{Arrivoc}

Archive for

Organic Chemistry
The Free Internet Journal

for Organic Chemistry
Paper

Arkivoc 2018, part v, 0-0

to be inserted by editorial office

\title{
A convenient route to novel fluorinated 1,2,4,3-triazaphospholo[1,5-a]pyridines and pyrido[1,2-b][1,2,4,5]triazaphosphinines
}

\author{
Mohammed A. Assiria,b, Somaia M. Abdel-Kariem", Tarik E. Alic ${ }^{*}$, and I. S. Yahiad,e \\ ${ }^{a}$ Advanced Materials and Green Chemistry, Chemistry Department, Faculty of Science, King Khalid University, \\ Abha, Saudi Arabia \\ ${ }^{b}$ Research Center for Advanced Materials Science (RCAMS), King Khalid University, Abha, Saudi Arabia. \\ 'Department of Chemistry, Faculty of Education, Ain Shams University, Roxy, Cairo, Egypt \\ ${ }^{d}$ Advanced Functional Materials \& Optoelectronic Laboratory (AFMOL), Department of Physics, Faculty of \\ Science, King Khalid University, Abha, Saudi Arabia \\ eNanoscience Laboratory for Environmental and Bio-medical Applications (NLEBA), Semiconductor Lab., \\ Department of Physics, Faculty of Education, Ain Shams University, Roxy, Cairo, Egypt \\ E-mail: tarik elsayed1975@yahoo.com; tarekelsaied@edu.asuedu.eg
}

Received 01-09-2018

Accepted 04-23-2018

Published on line $07-01-2018$

\section{Abstract}

A simple synthetic approach to the construction of novel fluorinated 5-oxo(thioxo)-2-oxido(sulfido)-1,2,4,3triazaphospholo[1,5-a]pyridines 2-14 and pyrido[1,2-b][1,2,4,5]triazaphosphinines 16, 19 and 22, was achieved. The method depends on the treatment of 1,6-diamino-4-(4-fluorophenyl)-2-oxo-1,2dihydropyridine-3,5-dicarbonitrile (1) with some different types of phosphorus reagents such as phosphorus acid, and their esters, phosphorus halides as well as phosphorus sulfides. Structures of all the synthesized products were established by elemental analysis and spectral tools.

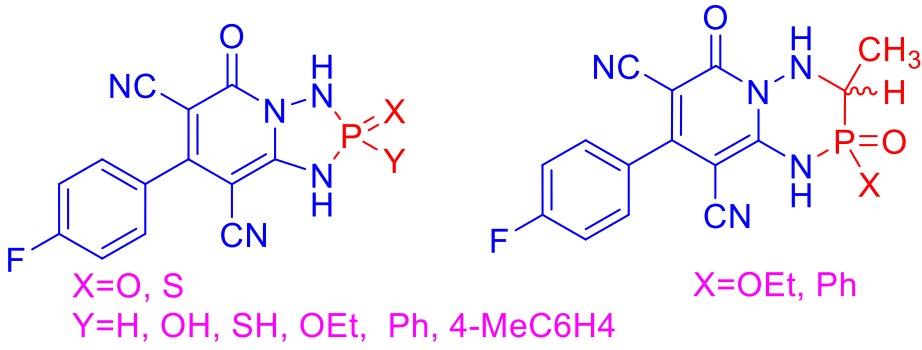

Keywords: 1,6-Diaminopyridine, cyclization, 1,2,4,3-triazaphospholes, 1,2,4,5-triazaphosphinines 
Phosphorus-nitrogen compounds have gained considerable attention due to their biological and pharmacological effects, such as antimicrobial, ${ }^{1}$ insecticidal, ${ }^{2}$ and herbicidal properties. ${ }^{3}$ Especially, different isomers of triazaphospholes possess multiple biological properties including antibacterial ${ }^{4}$ and antineoplastic activities. ${ }^{5}$ Also, several triazaphosphinine derivatives are present in the pharmaceutical field where they are used as antitumor agents. ${ }^{6-8}$ On the other hand, the pyridine ring is of considerable interest since it is the key component in a range of bioactive naturally occurring and synthetic compounds. ${ }^{9}$ The pyridine-3,5dicarbonitrile was chosen as an important structural scaffold for the design of a reaction-based library. ${ }^{10} \mathrm{~A}$ number of the researches reported the biological activities of pyridine dicarbonitrile as being analgesic, ${ }^{11}$ antiHIV, ${ }^{12}$ anti-Alzheimer, ${ }^{13}$ anticancer, ${ }^{14}$ anti-inflammatory and antibacterial agents. ${ }^{15}$ Because of the characteristic properties of the fluorine atom, such as its small size, strong electronegativity and the low polarizability of the $\mathrm{C}-\mathrm{F}$ bond, it have considerable effect on the biological properties of a molecule. ${ }^{16}$ The presence of fluorine into a drug causes simultaneous modulation of its electronic, lipophilic, and steric parameters, which lead to a strong influence in the pharmacokinetic and pharmacodynamics properties of drugs. ${ }^{17}$ In the light of these facts, and as a continuation of our reported work on construction of bioactive phosphorus heterocycles, ${ }^{18-20}$ the present work studies the chemical reactivity of 1,6 -diamino-4-(4fluorophenyl)-2-oxo-1,2-dihydropyridine-3,5-dicarbonitrile (1) towards some different phosphorus reagents, which lead to the formation of novel fluorine compounds containing functionalized 1,2,4,3triazaphospholo[1,5-a]pyridines and pyrido[1,2-b][1,2,4,5]triazaphosphinines.

\section{Results and Discussion}

The starting material, 1,6-diamino-4-(4-fluorophenyl)-2-oxo-1,2-dihydropyridine-3,5-dicarbonitrile (1) was synthesized in one step by the reaction of 4-fluorobenzaldehyde, malononitrile and cyanoacetohydrazide in absolute ethanol containing a few drops of piperidine as a catalyst ${ }^{21}$ (Scheme 1 ). The chemical structure of compound 1 was in accordance with its spectral data. The IR spectrum exhibited vibrational bands for $\mathrm{NH}_{2}$, $\mathrm{C} \equiv \mathrm{N}$, and $\mathrm{C}=\mathrm{O}$ at 3392-3111, 2219 and $1667 \mathrm{~cm}^{-1}$, respectively. The ${ }^{1} \mathrm{H}-\mathrm{NMR}$ spectrum showed signals due to two $\mathrm{NH}_{2}$ groups at $\delta 5.68$ and $7.97,8.48 \mathrm{ppm}$ and $A B$ system of phenyl group at $\delta 7.41$ and $7.59(J=9.2 \mathrm{~Hz})$ ppm. Also, the ${ }^{13} \mathrm{C}-\mathrm{NMR}$ spectrum displayed the aromatic carbon atoms and the nitrile groups at the expected chemical shifts.

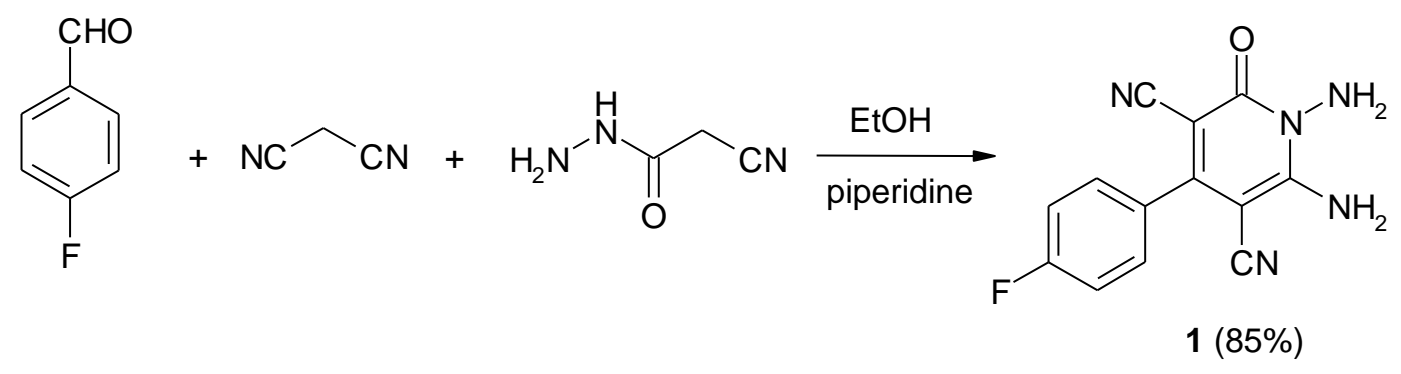

Scheme 1. Synthesis of 1,6-diamino-4-(4-fluorophenyl)-2-oxo-1,2-dihydropyridine-3,5-dicarbonitrile (1).

The 1,6-diamino groups are ready-made nucleophilic centers for the synthesis of fused phosphorus heterocyclic rings via their reaction with phosphorus reagents having labile halogen atoms. ${ }^{22}$ Thus, treatment 
of compound 1 with phenylphosphonic dichloride in dry dioxane containing two equivalent amounts of triethylamine led to the formation of 7-(4-fluorophenyl)-2-oxido-5-oxo-2-phenyl-1,2,3,5-tetrahydro[1,2,4,3] triazaphospholo[1,5-a]pyridine-6,8-dicarbonitrile (2) in moderate yield (Scheme 2). Similarly, compound 1 reacted with phosphorus oxychloride under the same reaction conditions to give the 2-hydroxy-1,2,4,3triazaphospholo[1,5-a]pyridine derivative 4 (Scheme 2). The proposed mechanism for this reaction can be explained by cyclization of 1,6-diaminopyridine 1 with phosphorus oxychloride to give the nonisolable intermediate $\mathbf{3}$ which underwent hydrolysis by the effect of air-moisture (Scheme 2). In a similar manner, treatment of compound 1 with phosphorus tribromide in dry dioxane containing triethylamine, did not give the expected 7-(4-fluorophenyl)-5-oxo-1,5-dihydro[1,2,4,3]triazaphospholo[1,5-a]pyridine-6,8-dicarbonitrile (5). This reaction gave the 1,2,4,3-triazaphospholo[1,5-a]pyridine-8-carboxamide derivative 6 in moderate yield. However, the product $\mathbf{5}$ was isolated from the reaction of hexaethylphosphorus triamide with compound $\mathbf{1}$ in dry dioxane (Scheme 3). We assumed that compound $\mathbf{5}$ underwent partial hydrolysis in situ for one nitrile group because of by-product $\mathrm{HBr}$ and air-moisture (Scheme 3 ). The IR spectra of compounds $\mathbf{2 , 4 , 5}$ and 6 showed absorption bands at regions 3371-3198 $\left(\mathrm{NH}_{2}, \mathrm{NH}\right)$ and $1229-1227(\mathrm{P}=\mathrm{O}) \mathrm{cm}^{-1}$. Also, the ${ }^{1} \mathrm{H}-\mathrm{NMR}$ spectra of these compounds revealed the $\mathrm{NH}$ protons at region $\delta 8.26-9.15 \mathrm{ppm}$, while the protons of $\mathrm{OH}$ and $\mathrm{CONH}_{2}$ in compounds 4 and 6 were observed at $\delta 3.38$ and $8.47 \mathrm{ppm}$, respectively. The ${ }^{13} \mathrm{C}-\mathrm{NMR}$ spectra of these compounds displayed the expected signals of all carbon atoms. The presence of the carbon atom of $\mathrm{CONH}_{2}$ in compound 6 at $\delta 170.6 \mathrm{ppm}$ supported the partial hydrolysis process. Moreover, the molecular ion peaks of these compounds were recorded at $m / z$ 391, 331, 297 and 315, respectively, in thier mass spectra. The ${ }^{31} \mathrm{P}-\mathrm{NMR}$ spectrum of compound 2 recorded a singlet at $\delta 32.1 \mathrm{ppm}$.
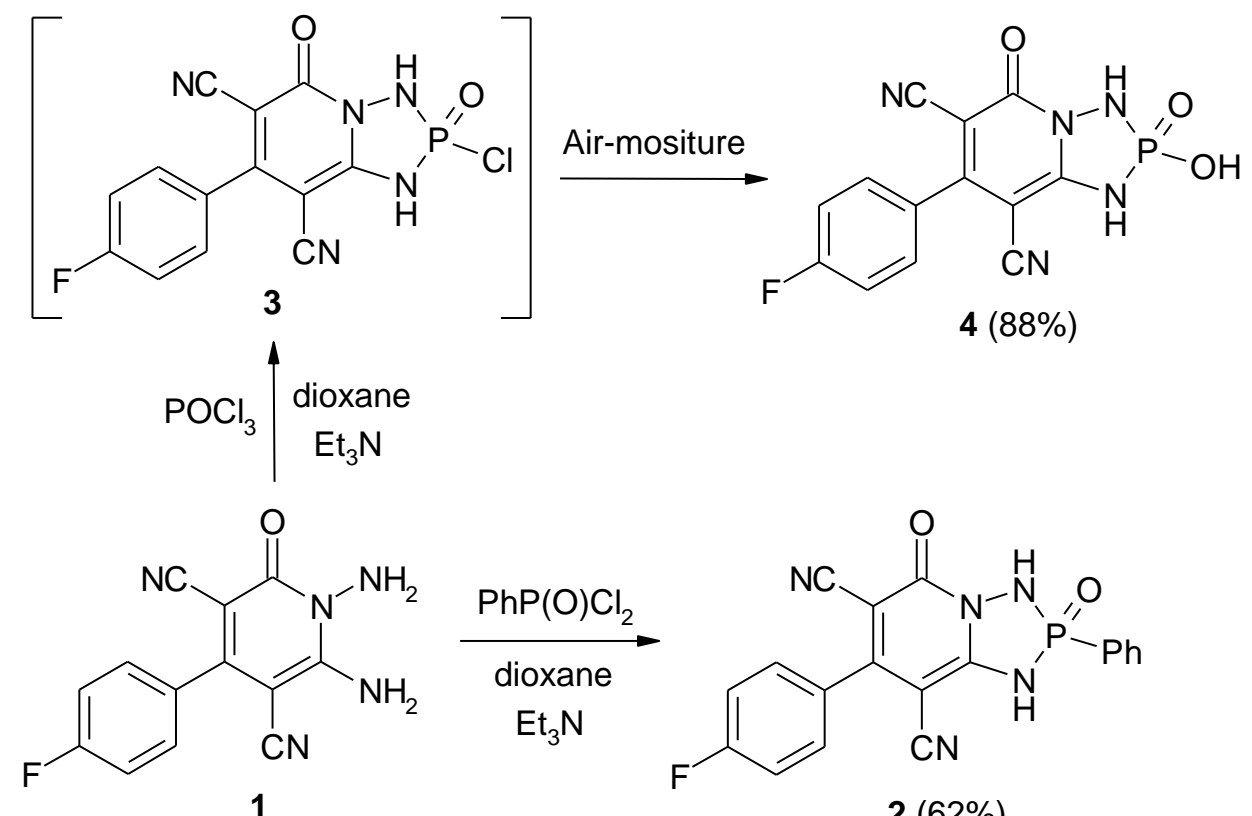

Scheme 2. Reaction of compound 1 with phenylphosphonic dichloride and phosphorus oxychloride. 


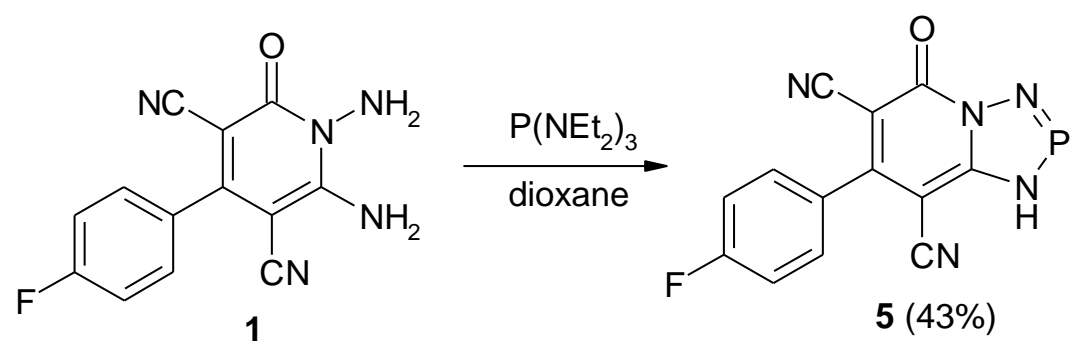

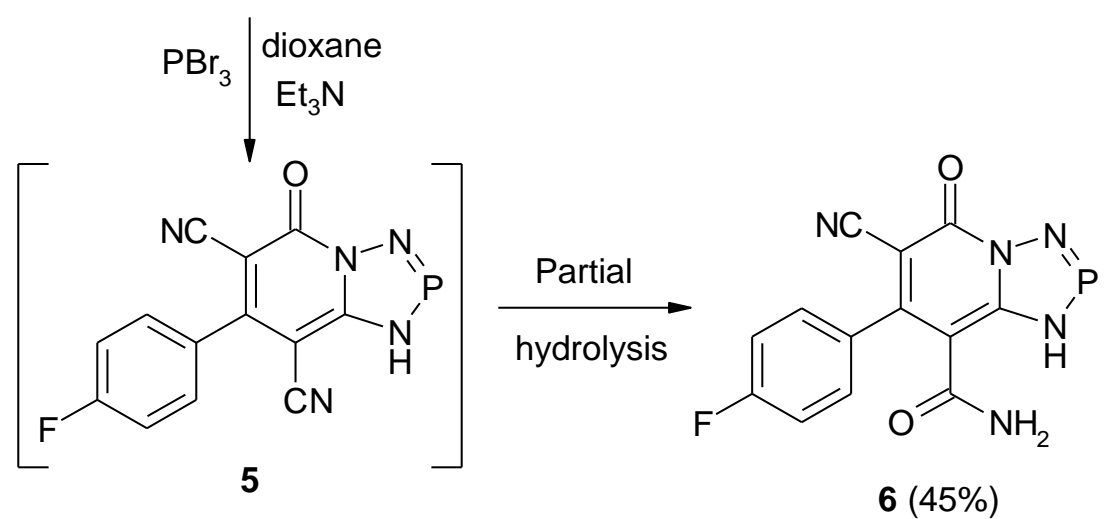

Scheme 3. Reaction of compound 1 with hexaethylphosphorus triamide and phosphorus tribromide.

We also studied the reaction of compound 1 with two examples of phosphorus sulfides. Thus, 1,6diamino-4-(4-fluorophenyl)-2-thioxo-1,2-dihydropyridine-3,5-dicarbonitrile (7) was isolated as a result of sulfuration process when compound 1 reacted with equivalent amount of phosphorus pentasulfide in dry dioxane (Scheme 4). The spectroscopic data of compound 7 confirmed the disappearance of $\mathrm{C}=\mathrm{O}$ group. In addition, its IR and ${ }^{13} \mathrm{C}-\mathrm{NMR}$ spectra revealed new $\mathrm{C}=\mathrm{S}$ group in them at $1164 \mathrm{~cm}^{-1}$ and $\delta 179.0 \mathrm{ppm}$, respectively. When this reaction was carried out by using two folds of phosphorus pentasulfide, the 2-sulfanyl2-sulfido-5-thioxo-1,2,3,5-tetrahydro[1,2,4,3]triazaphospholo[1,5-a]pyridine 8 was formed (Scheme 4). The product 8 was also isolated via treatment of the 1,6-diaminopyridine 7 with phosphorus pentasulfide under the same reaction conditions (Scheme 4). On the other hand, compound 1 was treated with Lawesson's reagent (LR) in dry dioxane to give a moderate yield of 7-(4-fluorophenyl)-2-(4-methoxyphenyl)-2-sulfido-5thioxo-1,2,3,5-tetrahydro-1,2,4,3-triazaphospholo[1,5-a]pyridine-6,8-dicarbonitrile (9) (Scheme 4). In addition, compound 9 was also obtained from treatment of compound 7 with LR in dry dioxane (Scheme 4). Similarly, treatment of compound 1 with 0,0 -diethyldithiophosphoric acid (formed in situ) in absolute ethanol yielded the 2-ethoxy-2-sulfido-1,2,3,5-tetrahydro-1,2,4,3-triazaphospholo[1,5-a]pyridine derivative 10 (Scheme 4). In the mass spectra of compounds $\mathbf{8}, \mathbf{9}$ and $\mathbf{1 0}$, they revealed their expected molecular ion peaks $\left(\mathrm{M}^{+}\right)$. The most characteristic signals in their ${ }^{1} \mathrm{H}-\mathrm{NMR}$ spectra are those of the sulfanyl, methoxy, and ethoxy protons. They appeared at $\delta 4.63(\mathrm{SH}), 3.81\left(\mathrm{OCH}_{3}\right)$, and 1.08, $3.46\left(\mathrm{CH}_{3} \mathrm{CH}_{2} \mathrm{O}\right) \mathrm{ppm}$. Also, the specific carbon atoms of $\mathrm{C}=\mathrm{S}$ groups of compounds 8 and $\mathbf{9}$ were observed at $\delta 179.2$ and $178.3 \mathrm{ppm}$, respectively, in their ${ }^{13} \mathrm{C}$-NMR spectra. Moreover, the ${ }^{31} \mathrm{P}-\mathrm{NMR}$ spectrum of compound 9 displayed a singlet at $\delta 54.5 \mathrm{ppm}$ which supported the proposed structure. ${ }^{23}$ 
<smiles>CCOP1(=S)Nc2c(C#N)c(-c3ccc(F)cc3)c(C#N)c(=O)n2N1</smiles>

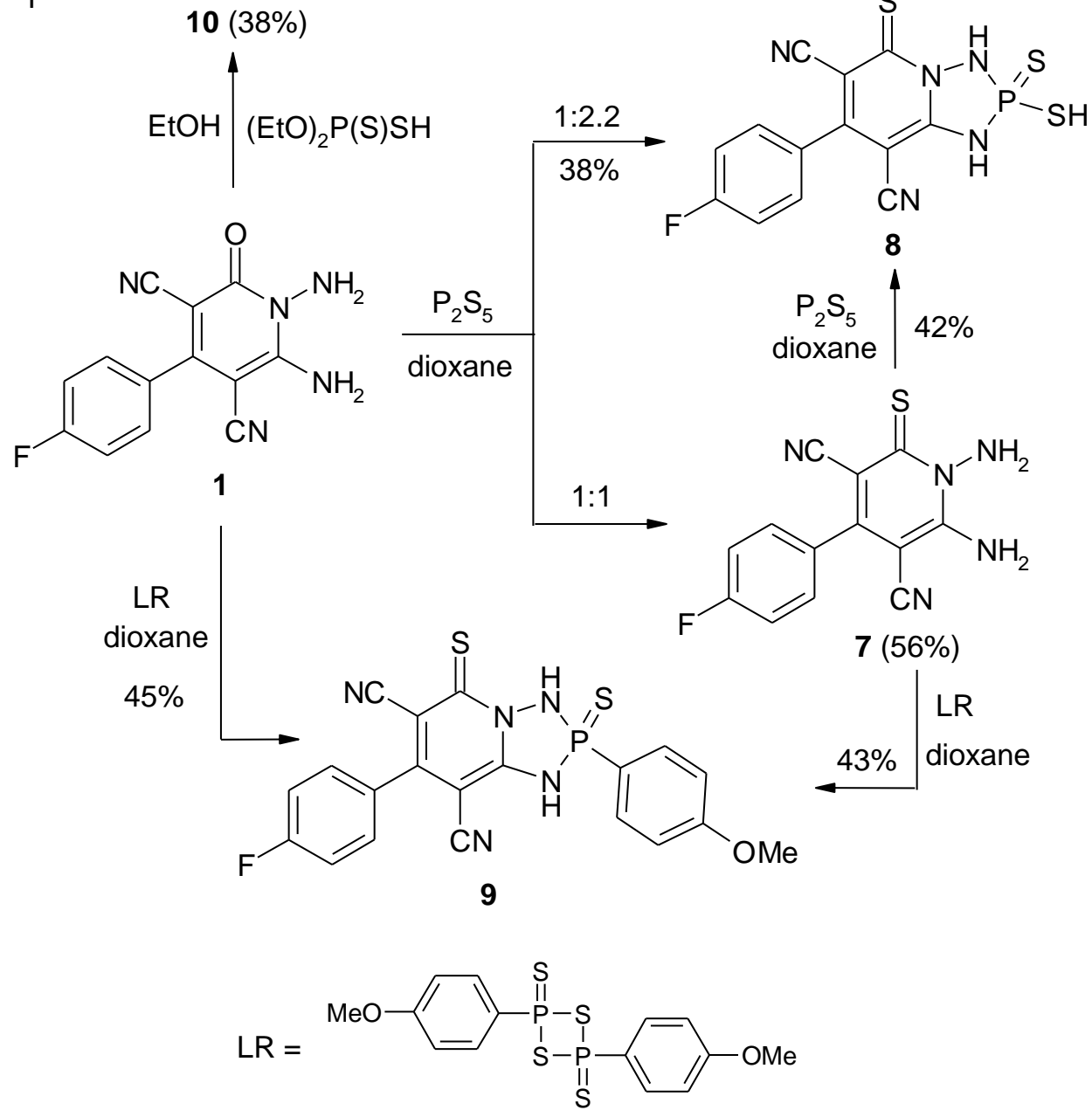

Scheme 4. Reaction of compound 1 with some phosphorus sulfides.

Next, the present study was extended to investigate the interaction of the 1,6-diaminopyridine 1 with three examples of phosphorus esters. Thus, when compound 1 was fused with triethyl phosphate at $80-90{ }^{\circ} \mathrm{C}$, the 2-ethoxy-7-(4-fluorophenyl)-2-oxido-2-oxo-1,2,3,5-tetrahydro[1,2,4,3]triazaphospholo[1,5-a]pyridine-6,8dicarbonitrile (11) was isolated (Scheme 5). In the same manner, the 1,2,4,3-triazaphospholo[1,5-a]pyridine derivatives 12 and 13 were produced by fusion of compound 1 with diethyl phosphite and tris(2-chloroethyl) phosphite, respectively (Scheme 5). The IR spectra of compounds 11-13 recorded the absorption bands of NH and $\mathrm{P}=\mathrm{O}$ groups at regions $3295-3429$ and $1228-1230 \mathrm{~cm}^{-1}$, respectively. The characteristic protons of these compounds were observed in their ${ }^{1} \mathrm{H}-\mathrm{NMR}$ spectra. For example, the $\mathrm{P}-\mathrm{H}$ proton was recorded as a doublet at $\delta 6.47\left(\mathrm{~J}_{\mathrm{PH}}=711 \mathrm{~Hz}\right)$ in compound 12, while the ethoxy protons of compound 11 were resonated as triplet and quartet at $\delta 1.21\left(\mathrm{CH}_{3}\right)$ and $3.06\left(\mathrm{CH}_{2}\right)$ ppm, respectively. Also, the chloroethoxy moiety in compound 13 was displayed as two triplets at $\delta 3.54$ and $3.83 \mathrm{ppm}$. Furthermore, the carbon atoms of the ethoxy fragments in compounds 11 and 13 were displayed at $\delta 18.5,60.0$ and 45.0, 62.5 ppm, respectively. Compounds 11-13 recorded the expected molecular ion peaks in their mass spectra. 
<smiles></smiles>
12 (40\%)
$\mathrm{P}\left(\mathrm{OCH}_{2} \mathrm{CH}_{2} \mathrm{Cl}\right)_{3} \mid \begin{gathered}\text { fusion } \\ 80-90^{\circ} \mathrm{C}\end{gathered}$<smiles>N#Cc1c(-c2ccc(F)cc2)c(C#N)c(=O)n2c1NP(OCCCl)N2</smiles>

13 (43\%)

Scheme 5. Reaction of compound 1 with some phosphorus esters.

Compound $\mathbf{1 3}$ was ready to cyclize into the annulated triheterocyclic system $\mathbf{1 4}$ by heating in absolute ethanol containing a few drops of triethylamine (Scheme 6). ${ }^{24}$ The oxazaphospholotriazaphospholopyridine structure 14 was deduced from analytical and spectroscopic data. In the IR spectrum, the only $\mathrm{NH}$ group was observed at $3417 \mathrm{~cm}^{-1}$. In the ${ }^{1} \mathrm{H}-\mathrm{NMR}$ spectrum, the protons of two methylene groups were observed at $\delta$ 2.91 and $3.60 \mathrm{ppm}$, while their resonances in ${ }^{13} \mathrm{C}-\mathrm{NMR}$ spectrum were at $\delta 42.5$ and $60.0 \mathrm{ppm}$. The presence of the molecular ion peak for compound 14 at $\mathrm{m} / \mathrm{z} 341$ was the strongest evidence for the cyclization process.

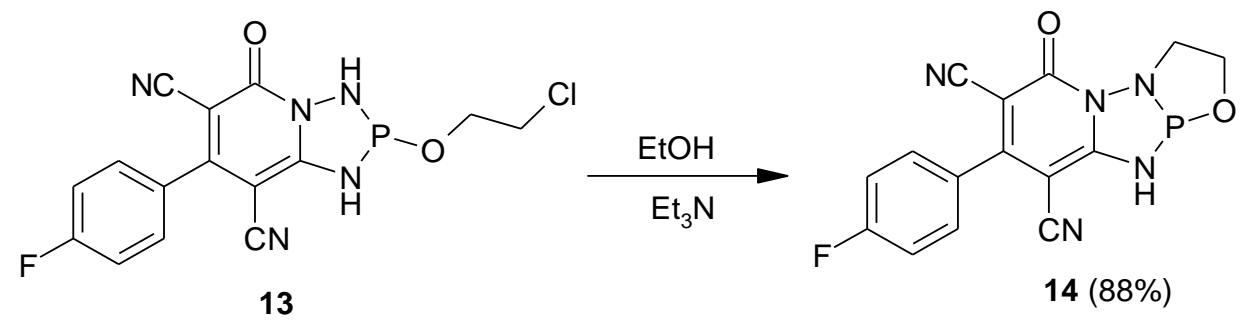

Scheme 6. Cyclization of compound 13 into 14.

The 1,6-diamino groups as active nucleophilic centers can be used to react with aldehyde and dialkyl phosphite under the Kabachnik-Fields reaction condition to form new 1,2,4,5-triazaphosphinine (cyclic $\alpha$ aminophosphonate). ${ }^{25,26}$ Thus, compound 1 condensed with acetaldehyde in the presence of diethyl phosphite or phenyl dichlorophosphine at room temperature, followed by heating under reflux to yield two isomeric forms of pyrido[1,2-b][1,2,4,5]triazaphosphinines 16 and 19, respectively (Scheme 7). The formation of product 16 took place easily via condensation of the more chemically active N-amino group with acetaldehyde, followed by phospha-Michael addition of phosphorus atom to form the nonisolable $\alpha$-aminophosphonate 15 . The latter intermediate underwent cyclization by removal of ethanol molecule (Scheme 7). ${ }^{27}$ Also, the formation of compound 19 occurred easily via condensation of the two amino groups with acetaldehyde and phenyl dichlorophosphine affording the nonisolable intermediate 17 which underwent 
hydrolysis of labile chlorine atom by the eliminated water to form the intermediate 18. This intermediate could easily transform into the isolated product 19 via phospha-Michael addition reaction (Scheme 7)..$^{28}$ The IR spectra of compounds 16 and 19 recorded the absorption bands of $\mathrm{P}=\mathrm{O}$ groups at 1236 and $1237 \mathrm{~cm}^{-1}$, respectively. In their ${ }^{1} \mathrm{H}-\mathrm{NMR}$ spectra, the $\mathrm{P}-\mathrm{CH}$ protons appeared at $\delta 4.50\left(\mathrm{q}, \mathrm{J}_{\mathrm{PCH}}=18.6 \mathrm{~Hz}\right)$ and $4.14-4.20$ (m) ppm, respectively, while the carbon atoms of the $\mathrm{P}-\mathrm{CH}$ moieties in their ${ }^{13} \mathrm{C}-\mathrm{NMR}$ spectra, were resonated at $\delta 53.5\left(\mathrm{~d}, J_{\mathrm{PC}}=150 \mathrm{~Hz}\right)$ and $45.5\left(\mathrm{~d}, J_{\mathrm{PC}}=138 \mathrm{~Hz}\right) \mathrm{ppm}$ for 16 and 19, respectively. The phosphorus chemical shift of compound 16 showed a singlet at $\delta 22.2 \mathrm{ppm}$ in its ${ }^{31} \mathrm{P}-\mathrm{NMR}$ spectrum which confirmed the proposed structure. The mass spectra of 16 and 19 recorded the expected molecular ion peaks at $\mathrm{m} / \mathrm{z} 387$ and 419 , respectively.

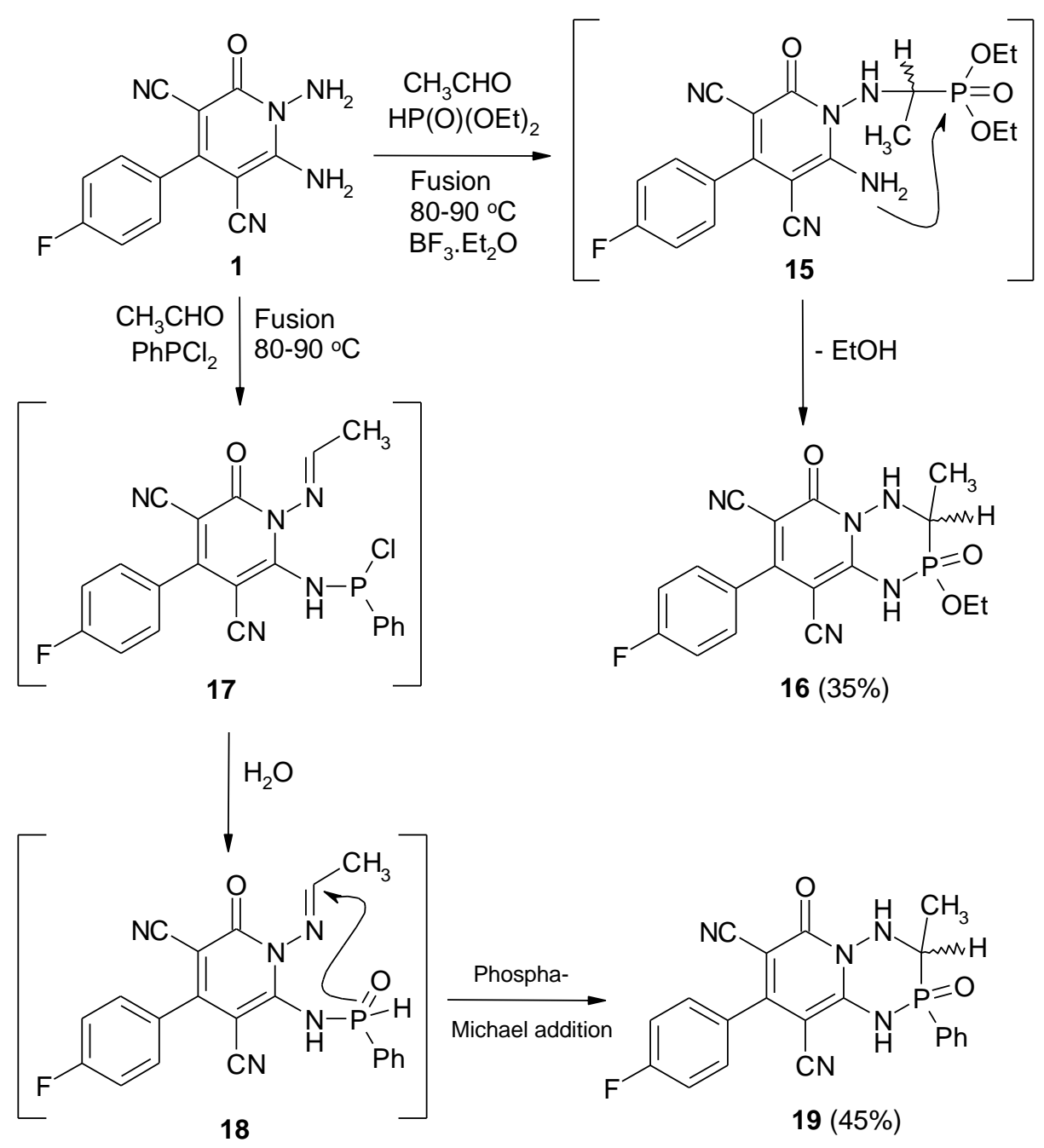

Scheme 7. Reaction of compound 1 with acetaldehyde in the presence of diethylphosphite and phenyl dichlorophosphine.

An addition of phosphorous acid to an acidic solution of compound $\mathbf{1}$ in the presence of formaldehyde led to the formation of the interesting novel pyrido[1,2-b][1,2,4,5]triazaphosphininyl methyl phosphonic acid 22 (Scheme 8). The reaction took place smoothly via condensation of $\mathrm{N}$-amino group with formaldehyde, followed by phospha-Michael addition of phosphorous acid to form the nonisolable aminophosphonic acid 20. The latter acid underwent cyclization by removal of water molecule to give the nonisolable pyrido[1,2-a] $[1,2,4,5]$ triazaphosphinine $\mathbf{2 1}$, that underwent additional methylphosphorylation process at $\mathrm{N}-1$ to isolate the 
novel pyrido[1,2-a][1,2,4,5]triazaphosphininylmethyl phosphonic acid 22 (Scheme 8). ${ }^{29}$ The IR spectrum of compound 22 showed absorption bands at $3418(\mathrm{br}, \mathrm{OH}, \mathrm{NH}), 2964\left(\mathrm{CH}_{\text {aliphatic }}\right)$ and $1230(\mathrm{P}=\mathrm{O}) \mathrm{cm}^{-1}$. In its ${ }^{1} \mathrm{H}-\mathrm{NMR}$ spectrum, the protons of $\mathrm{P}-\mathrm{CH}_{2}$ fragments were displayed as a multiplet at $\delta \quad 4.54-5.15 \mathrm{ppm}$, while the carbon atoms of these fragments were recorded as two doublets at $\delta 45.0$ and 50.5 ppm in the ${ }^{13} \mathrm{C}-\mathrm{NMR}$ spectrum. The ${ }^{31} \mathrm{P}-\mathrm{NMR}$ spectrum of compound $\mathbf{2 2}$ was the strongest evidence for the proposed structure, due to the presence of two signals at $\delta 11.7$ and $19.2 \mathrm{ppm} .{ }^{30}$ Finally, its molecular ion peak $\left(\mathrm{M}^{+}\right)$was observed at $m / z 408$, in the mass spectrum.<smiles>N#Cc1c(-c2ccc(F)cc2)c(C#N)c(=O)n(N)c1N</smiles>

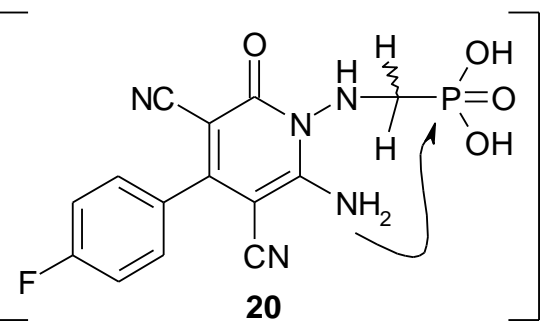<smiles>N#Cc1c(-c2ccc(F)cc2)c(C#N)c(=O)n2c1NP(=O)(O)CN2CP(=O)(O)O</smiles>

22 (55\%)

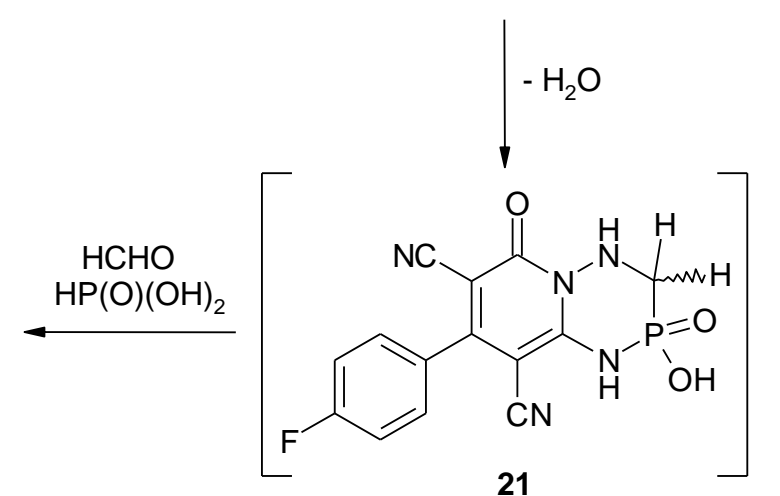

Scheme 8. Reaction of compound 1 with formaldehyde in the presence of phosphorous acid.

\section{Conclusions}

We suggested a simple method for the synthesis of some novel functionalized 1,2,4,3-triazaphospholo[1,5-a] pyridines 2-14 and pyrido[1,2-b][1,2,4,5]triazaphosphinine 16, 19 and 22 by the reaction of 1,6-diamino-4-(4fluorophenyl)-2-oxo-1,2-dihydropyridine-3,5-dicarbonitrile (1) with some different phosphorus reagents under mild reaction conditions.

\section{Experimental Section}

General. The melting points were determined in an open capillary tube on a digital Stuart SMP-3 apparatus. Infrared spectra were measured on a Perkin-Elmer 293 spectrophotometer using $\mathrm{KBr}$ disks. ${ }^{1} \mathrm{H}-\mathrm{NMR}$ spectra were recorded on a Bruker 400 and $600 \mathrm{MHz}$ spectrometer. ${ }^{13} \mathrm{C}$ - and ${ }^{31} \mathrm{P}-\mathrm{NMR}$ spectra were recorded on a Bruker $600 \mathrm{MHz}$ spectrometer operating at 150 and $242 \mathrm{MHz}$, respectively. Chemical shifts are reported in ppm with respect to the references and are stated relative to tetramethylsilane (TMS) for ${ }^{1} \mathrm{H}-$ and ${ }^{13} \mathrm{C}-\mathrm{NMR}$ and to $85 \%$ phosphoric acid for the ${ }^{31}$ P-NMR. Mass spectra were recorded on a Gas Chromatographic GCMSqp 1000 ex Shimadzu instrument at 70 ev. Elemental microanalysis was performed Perkin-Elmer 2400II at the 
Chemical War department, Ministry of Defense. The purity of the synthesized compounds was checked by thin layer chromatography (TLC) and elemental microanalysis.

Synthesis of 1,6-diamino-4-(4-fluorophenyl)-2-oxo-1,2-dihydropyridine-3,5-dicarbonitrile (1). A mixture of 4-fluorobenzaldehyde $(0.27 \mathrm{ml}, 2.5 \mathrm{mmol})$, malononitrile $(0.165 \mathrm{~g}, 2.5 \mathrm{mmol})$ and cyanoacetohydrazide $(0.25$ $\mathrm{g}, 2.5 \mathrm{mmol}$ ) in absolute ethanol $(30 \mathrm{ml})$ containing a few drops of piperidine, was heated under reflux for $5 \mathrm{~h}$. After cooling, the formed solid was filtered and recrystallized from DMF to afford beige crystals in $85 \%$ yield

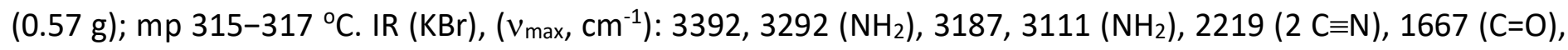
$1613(\mathrm{C}=\mathrm{C}) .{ }^{1} \mathrm{H}-\mathrm{NMR}\left(400 \mathrm{MHz}, \mathrm{DMSO}-\mathrm{d}_{6}\right): 5.68\left(\mathrm{~s}, 2 \mathrm{H}, \mathrm{NH}_{2}\right), 7.41$ (td, 2H, J 9.2 and $\left.2.8 \mathrm{~Hz}, \mathrm{Ar}-\mathrm{H}\right), 7.59$ (td, $2 \mathrm{H}, J$ 9.2 and $2.0 \mathrm{~Hz}, \mathrm{Ar}-\mathrm{H}), 7.97(\mathrm{~s}, 1 \mathrm{H}, \mathrm{NH}), 8.48(\mathrm{~s}, 1 \mathrm{H}, \mathrm{NH}) .{ }^{13} \mathrm{C}-\mathrm{NMR}\left(100 \mathrm{MHz}, \mathrm{DMSO}-d_{6}\right): 74.5(\mathrm{C}-5), 86.6 \quad(\mathrm{C}-$ 3), $115.5(\mathrm{C} \equiv \mathrm{N}), 116.0(\mathrm{C} \equiv \mathrm{N}), 130.6(\mathrm{C}-4), 130.9\left(\mathrm{C}-2^{\prime}, 6^{\prime}\right), 156.6\left(\mathrm{C}-3^{\prime}, 5^{\prime}\right), 158.6\left(\mathrm{C}-1^{\prime}\right), 159.1(\mathrm{C}-6), 161.8(\mathrm{C}-$ $\left.4^{\prime}\right), 164.3(\mathrm{C}=\mathrm{O})$. MS (El, m/z): $269\left(\mathrm{M}^{+}, 100 \%\right)$. Anal. calcd. for $\mathrm{C}_{13} \mathrm{H}_{8} \mathrm{FN} \mathrm{N}_{5} \mathrm{O}$ (269.23): C, 57.99; H, 2.99; N, 26.01\%. Found: $\mathrm{C}, 57.63 ; \mathrm{H}, 2.61 ; \mathrm{N}, 25.62 \%$.

Synthesis of 7-(4-fluorophenyl)-2-oxido-5-oxo-2-phenyl-1,2,3,5-tetrahydro[1,2,4,3]triazaphospholo[1,5-a] pyridine-6,8-dicarbonitrile (2). A solution of phenylphosphonic dichloride $(0.35 \mathrm{ml}, 2.5 \mathrm{mmol})$ in dry dioxane $(5 \mathrm{ml})$, was added dropwise to a solution of compound $1(0.675 \mathrm{~g}, 2.5 \mathrm{mmol})$ in dry dioxane $(30 \mathrm{ml})$ in presence of a catalytic amount of triethylamine $(0.35 \mathrm{ml}, 5 \mathrm{mmol})$ at $5-10{ }^{\circ} \mathrm{C}$ for 30 minutes. The mixture was heated under reflux for 4 hours then filtered off to remove triethyl ammonium chloride. The filtrate was concentrated into its third volume and left to cool. The formed solid was filtered off and crystallized from EtOH to give pale yellow solid in $62 \%$ yield $(0.61 \mathrm{~g}) ; \mathrm{mp} 287-289^{\circ} \mathrm{C}$. IR $(\mathrm{KBr}),\left(v_{\max }, \mathrm{cm}^{-1}\right): 3294,3198(2 \mathrm{NH})$, $2218(2 \mathrm{C} \equiv \mathrm{N}), 1671$ (C=O), 1629 (C=C), 1229 (P=O). ${ }^{1} \mathrm{H}-\mathrm{NMR}$ (400 MHz, DMSO-d $)$ ): 6.92 (dd, $1 \mathrm{H}, \mathrm{J} 8.4$ and 4.2 $\mathrm{Hz}, \mathrm{Ph}-\mathrm{H}), 7.18-7.26(\mathrm{~m}, 4 \mathrm{H}, \mathrm{Ph}-\mathrm{H}$ and $\mathrm{Ar}-\mathrm{H}), 7.40-7.41(\mathrm{~m}, 3 \mathrm{H}, \mathrm{Ph}-\mathrm{H}$ and $\mathrm{Ar}-\mathrm{H}), 7.50(\mathrm{dd}, 1 \mathrm{H}, \mathrm{J} 7.8 \mathrm{and} 2.4$ $\mathrm{Hz}, \mathrm{Ar}-\mathrm{H}), 8.79(\mathrm{~s}, 1 \mathrm{H}, \mathrm{NH}), 9.15(\mathrm{~s}, 1 \mathrm{H}, \mathrm{NH}) .{ }^{13} \mathrm{C}-\mathrm{NMR}\left(100 \mathrm{MHz}, \mathrm{DMSO}-d_{6}\right): 75.0$ (C-5), 87.1 (C-3), 116.2 $(C \equiv N), 116.4(C \equiv N), 120.2\left(C-3^{\prime \prime}, 5^{\prime \prime}\right), 127.6\left(C-2^{\prime \prime}, 6^{\prime \prime}\right), 130.3(C-4), 132.1\left(C-2{ }^{\prime}, 6^{\prime}\right), 135.4\left(C-4^{\prime \prime}\right), 137.4\left(C-1^{\prime \prime}\right)$,

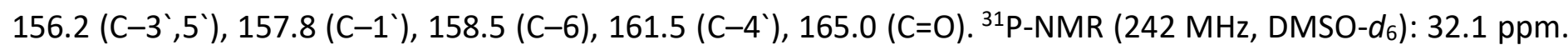
$\mathrm{MS}(\mathrm{El}, \mathrm{m} / \mathrm{z}): 393(\mathrm{M}+2,20 \%)$. Anal. calcd. for $\mathrm{C}_{19} \mathrm{H}_{11} \mathrm{FN}_{5} \mathrm{O}_{2} \mathrm{P}$ (391.30): C, 58.32; H, 2.83; N, 17.89\%. Found: C, $58.03 ; \mathrm{H}, 2.55 ; \mathrm{N}, 17.57 \%$.

Synthesis of 7-(4-fluorophenyl)-2-hydroxy-2-oxido-5-oxo-1,2,3,5-tetrahydro[1,2,4,3]triazaphospholo[1,5-a] pyridine-6,8-dicarbonitrile (4). A solution of phosphorus oxychloride $(0.25 \mathrm{ml}, 2.5 \mathrm{mmol})$ in dry dioxane $(5 \mathrm{ml})$, was added dropwise to a solution of compound 1 (0.675 g, $2.5 \mathrm{mmol})$ in dry dioxane (30 ml) in presence of a catalytic amount of triethylamine $(0.35 \mathrm{ml}, 5 \mathrm{mmol})$ at $5-10{ }^{\circ} \mathrm{C}$ for 30 minutes. The mixture was heated under reflux for 10 hours then filtered off to remove triethyl ammonium chloride. The filterate mixture was concentrated into its third volume and left to cool. The formed solid was filtered off and crystallized from diluted ethanol to give white solid in $88 \%$ yield $(0.73 \mathrm{~g}) ; \mathrm{mp} 303-306{ }^{\circ} \mathrm{C} . \mathrm{IR}(\mathrm{KBr}),\left(v_{\max }, \mathrm{cm}^{-1}\right): 3390(\mathrm{br}, \mathrm{OH})$, 3294, 3198 (2 NH), 2218 ( $2 \mathrm{C} \equiv \mathrm{N}), 1671(\mathrm{C}=\mathrm{O}), 1629$ (C=C), 1229 (P=O). ${ }^{1} \mathrm{H}-\mathrm{NMR}$ (400 MHz, DMSO-d 6 ): 3.38 (br, $1 \mathrm{H}, \mathrm{OH}), 7.38-7.43(\mathrm{~m}, 2 \mathrm{H}, \mathrm{Ar}-\mathrm{H}), 7.50(\mathrm{~d}, 1 \mathrm{H}, \mathrm{J} 8.4 \mathrm{~Hz}, \mathrm{Ar}-\mathrm{H}), 7.58-7.62(\mathrm{~m}, 1 \mathrm{H}, \mathrm{Ar}-\mathrm{H}), 8.26(\mathrm{~s}, 1 \mathrm{H}, \mathrm{NH}), 8.82$ $(\mathrm{s}, 1 \mathrm{H}, \mathrm{NH}) .{ }^{13} \mathrm{C}-\mathrm{NMR}\left(100 \mathrm{MHz}, \mathrm{DMSO}-d_{6}\right): 75.4(\mathrm{C}-5), 86.1(\mathrm{C}-3), 115.5(\mathrm{C} \equiv \mathrm{N}), 115.8(\mathrm{C} \equiv \mathrm{N}), 130.6(\mathrm{C}-4), 133.3$ $\left(C^{\prime} 2^{\prime}, 6^{\prime}\right), 155.4\left(C^{\prime} 3^{\prime}, 5^{\prime}\right), 157.0\left(C^{\prime} 1^{\prime}\right), 159.8(C-6), 160.8\left(C^{\prime} 4^{\prime}\right), 164.8$ (C=O). MS (EI, m/z): 333 (M+2, 8\%), 332 $(\mathrm{M}+1,9 \%), 331\left(\mathrm{M}^{+}, 13 \%\right)$. Anal. calcd. for $\mathrm{C}_{13} \mathrm{H}_{7} \mathrm{FN}_{5} \mathrm{O}_{3} \mathrm{P}$ (331.20): C, 47.14; $\mathrm{H}, 2.13 ; \mathrm{N}, 21.14 \%$. Found: $\mathrm{C}, 46.83$; $\mathrm{H}, 1.85 ; \mathrm{N}, 20.79 \%$.

Synthesis of 7-(4-fluorophenyl)- 5-oxo-1,5-dihydro[1,2,4,3]triazaphospholo[1,5-a]pyridine-6,8-dicarbonitrile (5). Hexaethylphosphorus triamide $(0.68 \mathrm{ml}, 2.5 \mathrm{mmol})$ was added to a solution of compound 1 (0.675 g, 2.5 $\mathrm{mmol})$ in dry dioxane $(30 \mathrm{ml})$. The mixture was heated under reflux for 10 hours. The solution was concentrated to its half volume and left to cool. The oily product was treated with ethyl acetate to give solid which was filtered off and crystallized from diluted ethanol to give pale yellow solid in yield $43 \%$ (0.32 g); mp 
200-201 ${ }^{\circ} \mathrm{C}$. IR $(\mathrm{KBr}),\left(v_{\max }, \mathrm{cm}^{-1}\right): 3297(\mathrm{NH}), 3050\left(\mathrm{C}-\mathrm{H}_{\text {arom }}\right), 2214(2 \mathrm{C} \equiv \mathrm{N}), 1665(\mathrm{C}=\mathrm{O}) .{ }^{1} \mathrm{H}-\mathrm{NMR}(400 \mathrm{MHz}$, DMSO-d $)$ : 7.28 (d, 2H, J 9.0 Hz, Ar-H), 7.65 (d, 2H, J 7.2 Hz, Ar-H), 8.71 (s, 1H, NH). ${ }^{13} \mathrm{C}-\mathrm{NMR}(100 \mathrm{MHz}, \mathrm{DMSO}-$ $\left.d_{6}\right): 75.5(\mathrm{C}-5), 82.9(\mathrm{C}-3), 110.7(\mathrm{C} \equiv \mathrm{N}), 112.6(\mathrm{C} \equiv \mathrm{N}), 133.7(\mathrm{C}-4), 133.9\left(\mathrm{C}-2^{\prime}, 6^{\prime}\right), 156.0\left(\mathrm{C}-3^{\prime}, 5^{\prime}\right), 158.0\left(\mathrm{C}-1^{\prime}\right)$, 160.1 (C-6), 161.8 (C-4), 164.9 (C=O). MS (EI, m/z): 297 ( $\left.\mathrm{M}^{+}, 18 \%\right)$. Anal. calcd. for $\mathrm{C}_{13} \mathrm{H}_{15} \mathrm{FN} \mathrm{F}_{5} \mathrm{OP}$ (297.18): C, $52.54 ; H, 1.70 ; N, 23.57$. Found: $C, 52.19 ; H, 1.53 ; N, 23.22 \%$.

Synthesis of 6-cyano-7-(4-fluorophenyl)-5-oxo-1,5-dihydro[1,2,4,3]triazaphospholo[1,5-a]pyridine-8carboxamide (6). A solution of phosphorus tribromide $(0.25 \mathrm{ml}, 2.5 \mathrm{mmol})$ in dry dioxane $(5 \mathrm{ml})$, was added dropwise to a solution of compound $1(0.67 \mathrm{~g}, 5 \mathrm{mmol})$ in dry dioxane $(60 \mathrm{ml})$ in presence of a catalytic amount of triethylamine $(0.7 \mathrm{ml}, 10 \mathrm{mmol})$ at $5-10{ }^{\circ} \mathrm{C}$ for 30 minutes. The mixture was heated under reflux for 10 hours. The reaction mixture was concentrated into its third volume and left to cool. The obtained oily product was dissolved in distilled water $(15 \mathrm{ml})$. The formed solid was filtered off and crystallized from diluted ethanol to give yellow solid in $45 \%$ yield $(0.35 \mathrm{~g})$; $\mathrm{mp} 294-297^{\circ} \mathrm{C}$. IR $(\mathrm{KBr}),\left(v_{\max }, \mathrm{cm}^{-1}\right): 3371,3283\left(\mathrm{NH}_{2}\right), 3200$ $(\mathrm{NH}), 2215(\mathrm{C} \equiv \mathrm{N}), 1682(\mathrm{C}=\mathrm{O}), 1666(\mathrm{C}=\mathrm{O}), 1607(\mathrm{C}=\mathrm{C}) .{ }^{1} \mathrm{H}-\mathrm{NMR}\left(400 \mathrm{MHz}, \mathrm{DMSO}-\mathrm{d}_{6}\right): 7.41$ (td, $2 \mathrm{H}, \mathrm{J} 8.8$ and $3.0 \mathrm{~Hz}, \mathrm{Ar}-\mathrm{H}), 7.58(\mathrm{td}, 2 \mathrm{H}, \mathrm{J} 8.8$ and $3.2 \mathrm{~Hz}, \mathrm{Ar}-\mathrm{H}), 8.47\left(\mathrm{br}, 2 \mathrm{H}, \mathrm{NH}_{2}\right), 8.79(\mathrm{br}, 1 \mathrm{H}, \mathrm{NH}) .{ }^{13} \mathrm{C}-\mathrm{NMR}(100 \mathrm{MHz}$, DMSO-d $d_{6}$ ): $78.5(C-5), 86.6(C-3), 116.2(C \equiv N), 130.6$ (C-4), $130.9\left(C-2^{\prime}, 6^{\prime}\right), 156.6\left(C^{\prime} 3^{\prime}, 5^{\prime}\right), 158.6\left(C-1^{\prime}\right), 159.1$ (C-6), $161.8\left(\mathrm{C}-4^{\prime}\right), 164.2(\mathrm{C}=\mathrm{O}), 170.6(\mathrm{C}=\mathrm{O})$. MS (El, $\left.\mathrm{m} / \mathrm{z}\right): 315\left(\mathrm{M}^{+}, 55 \%\right)$. Anal. calcd. for $\mathrm{C}_{13} \mathrm{H}_{7} \mathrm{FN}_{5} \mathrm{O}_{2} \mathrm{P}$ (315.20): C, 49.53; H, 2.23; N, 22.21\%. Found: C, 49.10; H, 1.94; N, 21.89\%.

Synthesis of 1,6-diamino-4-(4-fluorophenyl)-2-thioxo-1,2-dihydropyridine-3,5-dicarbonitrile (7). A mixture of phosphorus pentasulfide $(0.55 \mathrm{~g}, 2.5 \mathrm{mmol}$ ) and compound 1 (0.675 g, $2.5 \mathrm{mmol})$ in dry dioxane (40 ml), was heated under reflux for 5 hours. The reaction mixture was concentrated into its half volume and left to cool. The formed solid was filtered off and crystallized from ethanol to give orange crystalline solid in $56 \%$ yield $(0.40 \mathrm{~g})$; mp 285-286 ${ }^{\circ} \mathrm{C}$. IR ( $\left.\mathrm{KBr}\right),\left(v_{\max }, \mathrm{cm}^{-1}\right)$ : 3374, 3283, $3204\left(2 \mathrm{NH}_{2}\right), 2216(2 \mathrm{C} \equiv \mathrm{N}), 1604(\mathrm{C}=\mathrm{C}), 1164$ (C=S). ${ }^{1} \mathrm{H}-\mathrm{NMR}\left(400 \mathrm{MHz}, \mathrm{DMSO}-\mathrm{d}_{6}\right): 5.68\left(\mathrm{~s}, 2 \mathrm{H}, \mathrm{NH}_{2}\right), 7.41$ (td, 2H, J 8.8 and $2.4 \mathrm{~Hz}, \mathrm{Ar}-\mathrm{H}$ ), 7.59 (td, $2 \mathrm{H}, \mathrm{J}=8.0$ and $2.8 \mathrm{~Hz}, \mathrm{Ar}-\mathrm{H}), 8.47\left(\mathrm{~s}, 2 \mathrm{H}, \mathrm{NH}_{2}\right) .{ }^{13} \mathrm{C}-\mathrm{NMR}\left(100 \mathrm{MHz}, \mathrm{DMSO}-d_{6}\right): 74.4 \quad(\mathrm{C}-5), 86.6(\mathrm{C}-3), 115.6(\mathrm{C} \equiv \mathrm{N}), 116.2$ $(C \equiv N), 130.6(C-4), 131.0\left(C-2^{\prime}, 6^{\prime}\right), 156.6\left(C-3^{\prime}, 5^{\prime}\right), 158.6\left(C-1^{\prime}\right), 159.1$ (C-6), 161.8 (C-4'), 179.0 (C=S). MS (EI, $\mathrm{m} / \mathrm{z}): 285\left(\mathrm{M}^{+}, 100 \%\right)$. Anal. calcd. for $\mathrm{C}_{13} \mathrm{H}_{8} \mathrm{FN}_{5} \mathrm{~S}$ (285.30): C, 54.72; H, 2.82; N, 24.54; S, 11.23\%. Found: $\mathrm{C}$, $54.33 ; \mathrm{H}, 2.54 ; \mathrm{N}, 24.11 ; \mathrm{S}, 10.85 \%$.

Synthesis of 7-(4-fluorophenyl)-2-sulfanyl-2-sulfido-5-thioxo-1,2,3,5-tetrahydro[1,2,4,3]triazaphospholo [1,5-a]pyridine-6,8-dicarbonitrile (8). Method A. A mixture of phosphorus pentasulfide (0.55 g, $2.5 \mathrm{mmol})$ and compound $7(0.285 \mathrm{~g}, 1 \mathrm{mmol})$ in dry dioxane $(20 \mathrm{ml})$, was heated under reflux for 8 hours. The reaction mixture was concentrated into its half volume and left to cool. The formed solid was filtered off and crystallized from ethanol to give orange solid in in $42 \%$ yield $(0.16 \mathrm{~g}) ; \mathrm{mp} 240-242{ }^{\circ} \mathrm{C}$. Method B. A mixture of phosphorus pentasulfide $(1.22 \mathrm{~g}, 5.5 \mathrm{mmol})$ and compound $1(0.675 \mathrm{~g}, 2.5 \mathrm{mmol})$ in dry dioxane $(40 \mathrm{ml})$, was heated under reflux for 8 hours. The reaction mixture was concentrated into its half volume and left to cool. The formed solid was filtered off and crystallized from ethanol to give orange crystalline solid in yield 38\% (0.36 g); mp 242-243 ${ }^{\circ} \mathrm{C}$. IR ( $\left.\mathrm{KBr}\right),\left(v_{\max }, \mathrm{cm}^{-1}\right)$ : 3303, $3199(2 \mathrm{NH}), 2700(\mathrm{br}, \mathrm{SH})$, $2216(2 \mathrm{C} \equiv \mathrm{N}), 1608$ ( $\mathrm{C}=\mathrm{C}), 1163$ (C=S), $764(\mathrm{P}=\mathrm{S}) .{ }^{1} \mathrm{H}-\mathrm{NMR}$ (400 MHz, DMSO-d $)$ ) 4.63 (brs, 1H, SH), 7.12 (t, 2H, J $7.2 \mathrm{~Hz}, \mathrm{Ar}-\mathrm{H}), 7.48$ (t, 2H, J $8.0 \mathrm{~Hz}, \mathrm{Ar}-\mathrm{H}), 8.99(\mathrm{~s}, 1 \mathrm{H}, \mathrm{NH}), 9.55$ (brs, $1 \mathrm{H}, \mathrm{NH}) .{ }^{13} \mathrm{C}-\mathrm{NMR}\left(100 \mathrm{MHz}, \mathrm{DMSO}-d_{6}\right)$ : $75.7(\mathrm{C}-5), 85.8(\mathrm{C}-3), 111.2(\mathrm{C} \equiv \mathrm{N}), 112.4(\mathrm{C} \equiv \mathrm{N}), 131.9(\mathrm{C}-4), 132.9\left(\mathrm{C}-2^{\prime}, 6^{\prime}\right), 156.0\left(\mathrm{C}-3^{\prime}, 5^{\prime}\right), 158.3^{\prime}\left(\mathrm{C}-1^{\prime}\right)$, 159.6 (C-6), 161.2 (C-4), 179.2 (C=S). MS (EI, m/z): 381 (M+2, 2\%), $380(\mathrm{M}+1,7 \%), 379$ (M+, 35\%). Anal. calcd. for $\mathrm{C}_{13} \mathrm{H}_{7} \mathrm{FN}_{5} \mathrm{PS}_{3}$ (379.39): C, 41.15; H, 1.86; N, 18.46; S, 25.35\%. Found: C, 40.79; H, 1.59; N, 18.08; S, $25.02 \%$.

Synthesis of 7-(4-fluorophenyl)-2-(4-methoxyphenyl)-5-oxo-2-sulfido-5-thioxo-1,2,3,5-tetrahydro[1,2,4,3] triazaphospholo[1,5-a]pyridine-6,8-dicarbonitrile (9). Lawesson's reagent (0.5 g, $1.25 \mathrm{mmol})$ was added to a solution of compound $1(0.330 \mathrm{~g}, 1.25 \mathrm{mmol})$ or compound $7(0.356,1.25 \mathrm{mmol})$ in dry dioxane $(30 \mathrm{ml})$. The mixtures were heated under reflux for 8 hours. The solutions were concentrated to their half volumes and left 
to cool. The oily products were treated with diethyl ether to give solids which were filtered off and crystallized from diluted ethanol to give orange solids in $45 \%$ yield $(0.25 \mathrm{~g})$ and $43 \%(0.24 \mathrm{~g})$, respectively; $\mathrm{mp} 278-280{ }^{\circ} \mathrm{C}$.

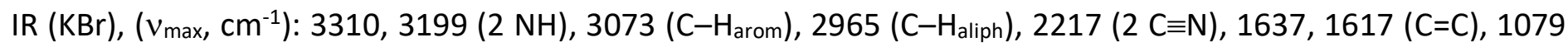
$(\mathrm{O}-\mathrm{C}), 844(\mathrm{P}=\mathrm{S}) .{ }^{1} \mathrm{H}-\mathrm{NMR}\left(400 \mathrm{MHz}, \mathrm{DMSO}-\mathrm{d}_{6}\right): 3.81\left(\mathrm{~s}, 3 \mathrm{H}, \mathrm{OCH}_{3}\right), 6.53(\mathrm{~s}, 1 \mathrm{H}, \mathrm{NH}), 7.39-7.45(\mathrm{~m}, 4 \mathrm{H}, \mathrm{Ar}-\mathrm{H})$, 7.57-7.63 (m, 4H, Ar-H), $8.76(\mathrm{~s}, 1 \mathrm{H}, \mathrm{NH}) .{ }^{13} \mathrm{C}-\mathrm{NMR}\left(100 \mathrm{MHz}, \mathrm{DMSO}-d_{6}\right): 55.0\left(\mathrm{OCH}_{3}\right), 74.5$ (C-5), $86.6(\mathrm{C}-3)$, $115.8(\mathrm{C} \equiv \mathrm{N}), 116.2(\mathrm{C} \equiv \mathrm{N}), 121.5\left(\mathrm{C}-3^{\prime \prime}, 5^{\prime \prime}\right), 130.5\left(\mathrm{C}-2^{\prime \prime}, 6^{\prime \prime}\right), 130.7(\mathrm{C}-4), 130.8\left(\mathrm{C}-2^{\prime}, 6^{\prime}\right), 132.0\left(\mathrm{C}-1^{\prime \prime}\right), 153.6$

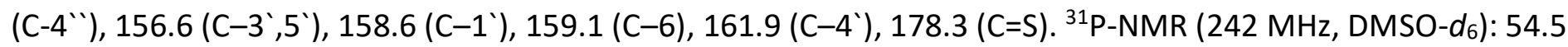
ppm. MS (El, $\mathrm{m} / \mathrm{z}): 453\left(\mathrm{M}^{+}, 20 \%\right)$. Anal. calcd. for $\mathrm{C}_{20} \mathrm{H}_{13} \mathrm{FN}_{5} \mathrm{OPS}$ (453.46): C, 52.97; H, 2.89; N, 15.44; S, $14.14 \%$. Found: $C, 52.59 ; \mathrm{H}, 2.61 ; \mathrm{N}, 15.09 ; \mathrm{S}, 13.79 \%$.

Synthesis of 2-ethoxy-7-(4-fluorophenyl)-5-oxo-2-sulfido-1,2,3,5-tetrahydro[1,2,4,3]triazaphospholo[1,5-a] pyridine-6,8-dicarbonitrile (10). A solution of phosphorus pentasulfide $(1.11 \mathrm{~g}, 5 \mathrm{mmol})$ in absolute ethanol $(30 \mathrm{ml})$ was heated under reflux for 1 hour to give 0,O-diethyldithiophosphoric acid (formed in situ). Compound 1 ( $0.675 \mathrm{~g}, 5 \mathrm{mmol}$ ) was added to the previous ethanolic solution. The mixture was heated under reflux for 8 hours. The reaction mixture was concentrated into its half volume and left to cool. After adding some water, the formed solid was filtered off and crystallized from diluted ethanol to give yellow crystals in

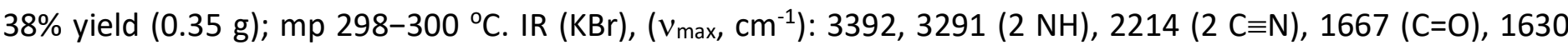
$(\mathrm{C}=\mathrm{C}), 1111$ (P-O-C), 704 (P=S). ${ }^{1} \mathrm{H}-\mathrm{NMR}\left(400 \mathrm{MHz}, \mathrm{DMSO}-\mathrm{d}_{6}\right): 1.08$ (t, 3H, J $\left.7.2 \mathrm{~Hz}, \mathrm{CH}_{3}\right), 3.46$ (q, $2 \mathrm{H}, \mathrm{J} 7.2 \mathrm{~Hz}$, $\mathrm{CH}_{2}$ ), $7.41(\mathrm{td}, 2 \mathrm{H}, J 8.8$ and $2.0 \mathrm{~Hz}, \mathrm{Ar}-\mathrm{H}), 7.59(\mathrm{td}, 2 \mathrm{H}, J 6.4$ and $2.4 \mathrm{~Hz}, \mathrm{Ar}-\mathrm{H}), 8.47(\mathrm{~s}, 1 \mathrm{H}, \mathrm{NH}), 9.26(\mathrm{~s}, 1 \mathrm{H}$, $\mathrm{NH}) .{ }^{13} \mathrm{C}-\mathrm{NMR}\left(100 \mathrm{MHz}, \mathrm{DMSO}-d_{6}\right): 18.5\left(\mathrm{CH}_{3}\right), 56.0\left(\mathrm{CH}_{2}\right), 74.5(\mathrm{C}-5), 86.6(\mathrm{C}-3), 115.5(\mathrm{C} \equiv \mathrm{N}), 116.2(\mathrm{C} \equiv \mathrm{N})$,

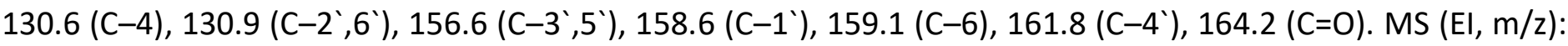
375 (M+35). Anal. calcd. for $\mathrm{C}_{15} \mathrm{H}_{11} \mathrm{FN}_{5} \mathrm{O}_{2} \mathrm{PS}$ (375.32): $\mathrm{C}, 48.00 ; \mathrm{H}, 2.95 ; \mathrm{N}, 18.65 ; \mathrm{S}, 8.52 \%$. Found: $\mathrm{C}, 47.63$; $\mathrm{H}, 2.61 ; \mathrm{N}, 18.28 ; \mathrm{S}, 8.09 \%$.

Synthesis of 2-ethoxy-7-(4-fluorophenyl)-2-oxido-5-oxo-1,2,3,5-tetrahydro[1,2,4,3]triazaphospholo[1,5-a] pyridine-6,8-dicarbonitrile (11). A mixture of triethyl phosphate $(0.85 \mathrm{ml}, 5 \mathrm{mmol}$ ) and compound 1 (0.67 g, $2.5 \mathrm{mmol}$ ) was fused on water bath for 10 hours. The oily product was dissolved in hot diluted ethanol and left to cool. The formed solid was filtered off and dried to give red solid in $57 \%$ yield $(0.52 \mathrm{~g}) ; \mathrm{mp} 262-265{ }^{\circ} \mathrm{C}$. IR $(\mathrm{KBr}),\left(v_{\max }, \mathrm{cm}^{-1}\right): 3429(\mathrm{br}, 2 \mathrm{NH}), 2976,2935\left(\mathrm{C}-\mathrm{H}_{\text {aliph }}\right), 2213(2 \mathrm{C} \equiv \mathrm{N}), 1660(\mathrm{C}=\mathrm{O}), 1600(\mathrm{C}=\mathrm{C}), 1228(\mathrm{P}=\mathrm{O})$, 1093 (P-O-C). ${ }^{1} \mathrm{H}-\mathrm{NMR}\left(400 \mathrm{MHz}, \mathrm{DMSO}-\mathrm{d}_{6}\right): 1.21$ (t, 3H, J $\left.7.2 \mathrm{~Hz}, \mathrm{CH}_{3}\right), 3.06$ (q, 2H, J 7.2 Hz, CH ), 5.69 (brs, $1 \mathrm{H}, \mathrm{NH}), 7.41(\mathrm{td}, 2 \mathrm{H}, J 9.2$ and $2.4 \mathrm{~Hz}, \mathrm{Ar}-\mathrm{H}), 7.58(\mathrm{td}, 2 \mathrm{H}, J 8.4$ and $2.8 \mathrm{~Hz}, \mathrm{Ar}-\mathrm{H}), 8.49(\mathrm{brs}, 1 \mathrm{H}, \mathrm{NH}) . \quad{ }^{13} \mathrm{C}-$ NMR (100 MHz, DMSO-d $): 18.5\left(\mathrm{CH}_{3}\right), 60.0\left(\mathrm{CH}_{2}\right), 74.5(\mathrm{C}-5), 86.6(\mathrm{C}-3), 115.6(\mathrm{C} \equiv \mathrm{N}), 116.2(\mathrm{C} \equiv \mathrm{N}), 130.6$ (C-4), $131.0\left(C-2^{\prime}, 6^{\prime}\right), 156.5$ (C-3',5'), 158.6 (C-1'), 159.1 (C-6), 161.8 (C-4'), 164.2 (C=O). MS (El, m/z): 361 $(\mathrm{M}+2,5 \%), 360(\mathrm{M}+1,18 \%)$. Anal. calcd. for $\mathrm{C}_{15} \mathrm{H}_{11} \mathrm{FN}_{5} \mathrm{O}_{3} \mathrm{P}$ (359.25): C, 50.15; H, 3.08; N, 19.49. Found: $\mathrm{C}$, 49.78; $\mathrm{H}, 2.81 ; \mathrm{N}, 19.12 \%$.

Synthesis of 7-(4-fluorophenyl)-2-oxido-5-oxo-1,2,3,5-tetrahydro[1,2,4,3]triazaphospholo[1,5-a]pyridine6,8-dicarbonitrile (12). A mixture of diethyl phosphite $(0.7 \mathrm{ml}, 5 \mathrm{mmol})$ and compound 1 (0.67 g, $2.5 \mathrm{mmol})$ was fused on water bath for 6 hours. The oily product was dissolved in hot diluted ethanol and left to cool. The formed solid was filtered off and dried to give orange solid in $40 \%$ yield $(0.31 \mathrm{~g})$; mp $204-206{ }^{\circ} \mathrm{C}$. IR $(\mathrm{KBr})$, $\left(v_{\max }, \mathrm{cm}^{-1}\right)$ : 3430, $3300(\mathrm{br}, 2 \mathrm{NH}), 2216(2 \mathrm{C} \equiv \mathrm{N}), 1667(\mathrm{C}=\mathrm{O}), 1604(\mathrm{C}=\mathrm{C}), 1230(\mathrm{P}=\mathrm{O}) .{ }^{1} \mathrm{H}-\mathrm{NMR}(400 \mathrm{MHz}$, DMSO-d 6 ): $6.47(1 \mathrm{H}, \mathrm{d}, J 711 \mathrm{~Hz}, \mathrm{P}-\mathrm{H}), 6.22(\mathrm{t}, 1 \mathrm{H}, J 6 \mathrm{~Hz}, \mathrm{NH}), 7.39$ (dd, 2H, J 9.2 and $1.2 \mathrm{~Hz}, \mathrm{Ar}-\mathrm{H}), \quad 7.53-$ $7.57(\mathrm{~m}, 2 \mathrm{H}, \mathrm{Ar}-\mathrm{H}), 8.38$ (brs, $1 \mathrm{H}, \mathrm{NH}) .{ }^{13} \mathrm{C}-\mathrm{NMR}\left(100 \mathrm{MHz}, \mathrm{DMSO}-d_{6}\right): 76.0(\mathrm{C}-5), 82.0(\mathrm{C}-3), 115.6(\mathrm{C} \equiv \mathrm{N})$,

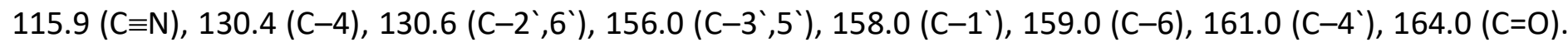
MS (El, $m / z): 315\left(\mathrm{M}^{+}, 18 \%\right)$. Anal. calcd. for $\mathrm{C}_{13} \mathrm{H}_{7} \mathrm{FN}_{5} \mathrm{O}_{2} \mathrm{P}$ (315.20): C, 49.53; $\mathrm{H}, 2.23 ; \mathrm{N}, 22.21 \%$. Found: $\mathrm{C}$, 49.16; H, 1.90; N, 21.86\%.

Synthesis of 2-(2-chloroethoxy)-7-(4-fluorophenyl)-5-oxo-1,2,3,5-tetrahydro[1,2,4,3]triazaphospholo[1,5-a] pyridine-6,8-dicarbonitrile (13). A mixture of tris(2-chloroethyl)phosphite $(0.9 \mathrm{ml}, 5 \mathrm{mmol})$ and compound 1 
$(0.67 \mathrm{~g}, 2.5 \mathrm{mmol})$ was fused on water bath for 8 hours. The oily product was dissolved in hot diluted ethanol and left to cool. The formed solid was filtered off and dried to give red solid in 43\% yield (0.41 g); mp 205-208 ${ }^{\circ} \mathrm{C}$. IR $(\mathrm{KBr}),\left(v_{\max }, \mathrm{cm}^{-1}\right)$ : 3295, $3396(2 \mathrm{NH}), 2904\left(\mathrm{C}-\mathrm{H}_{\text {aliph }}\right), 2217(2 \mathrm{C} \equiv \mathrm{N}), 1666(\mathrm{C}=\mathrm{O}), 1631(\mathrm{C}=\mathrm{C}), 1050$ (P-O-C). ${ }^{1} \mathrm{H}-\mathrm{NMR}\left(400 \mathrm{MHz}, \mathrm{DMSO}-\mathrm{d}_{6}\right): 3.54$ (t, $\left.2 \mathrm{H}, J 5.6 \mathrm{~Hz}, \mathrm{CH}_{2} \mathrm{Cl}\right), 3.83\left(\mathrm{t}, 2 \mathrm{H}, J 4.8 \mathrm{~Hz}, \mathrm{CH}_{2} \mathrm{O}\right), 5.67$ (brs, $1 \mathrm{H}$, $\mathrm{NH}), 7.41(\mathrm{t}, 2 \mathrm{H}, J=8.8 \mathrm{~Hz}, \mathrm{Ar}-\mathrm{H}), 7.58(\mathrm{t}, 2 \mathrm{H}, J=8.4 \mathrm{~Hz}, \mathrm{Ar}-\mathrm{H}), 8.47(\mathrm{br}, 1 \mathrm{H}, \mathrm{NH}) .{ }^{13} \mathrm{C}-\mathrm{NMR}\left(100 \mathrm{MHz}, \mathrm{DMSO}-d_{6}\right)$ : $45.0\left(\mathrm{CH}_{2} \mathrm{Cl}\right), 62.5\left(\mathrm{CH}_{2} \mathrm{O}\right), 74.5(\mathrm{C}-5), 86.6(\mathrm{C}-3), 115.6(\mathrm{C} \equiv \mathrm{N}), 116.2(\mathrm{C} \equiv \mathrm{N}), 130.6(\mathrm{C}-4), 130.9\left(\mathrm{C}-2^{\prime}, 6^{\prime}\right), 156.6$ $\left(C-3^{\prime}, 5^{\prime}\right), 158.6\left(C-1^{\prime}\right), 159.1$ (C-6), $161.0(C-4), 164.0(C=0) . M S(E I, m / z): 379(M+2,5 \%), 377\left(M^{+}, 12 \%\right)$. Anal. calcd. for $\mathrm{C}_{15} \mathrm{H}_{10} \mathrm{ClFN}_{5} \mathrm{O}_{2} \mathrm{P}$ (377.7): $\mathrm{C}, 47.70 ; \mathrm{H}, 2.66 ; \mathrm{N}, 18.54 \%$. Found: $\mathrm{C}, 47.35 ; \mathrm{H}, 2.29 ; \mathrm{N}, 18.19 \%$.

Synthesis of 8-(4-fluorophenyl)-6-oxo-2,3,6,10-tetrahydro[1,3,2]oxazaphospholo[3',2':2,3][1,2,4,3]triazaphospholo[1,5-a]pyridine-7,9-dicarbonitrile (14). A solution of compound 13 (0.38 g, $1 \mathrm{mmol})$ was heated in absolute ethanol containing a few drops of triethylamine for 12 hours. After cooling, the solution was poured into ice. The formed solid was filtered off and crystallized from diluted ethanol to give brick red solid in $88 \%$ yield $(0.3 \mathrm{~g})$; mp $123-125^{\circ} \mathrm{C}$. IR $(\mathrm{KBr}),\left(v_{\max }, \mathrm{cm}^{-1}\right)$ : $3417(\mathrm{br}, \mathrm{NH}), 2964\left(\mathrm{C}-\mathrm{H}_{\text {aliph }}\right), 2219(2 \mathrm{C} \equiv \mathrm{N}), 1660(\mathrm{C}=\mathrm{O})$, 1603 (C=C), 1039 (P-O-C). ${ }^{1} \mathrm{H}-\mathrm{NMR}$ (400 MHz, DMSO-d 6 ): 2.91 (s, 2H, CH $\mathrm{CH}_{2} \mathrm{~N}$ ), 3.60 (brs, 2H, CH $\left.{ }_{2} \mathrm{O}\right), 7.41$ (td, $2 \mathrm{H}$, J 8.8 and $2.0 \mathrm{~Hz}, \mathrm{Ar}-\mathrm{H}), 7.59(\mathrm{td}, 2 \mathrm{H}, J 8.0$ and $2.4 \mathrm{~Hz}, \mathrm{Ar}-\mathrm{H}), 7.97(\mathrm{~s}, 1 \mathrm{H}, \mathrm{NH}) .{ }^{13} \mathrm{C}-\mathrm{NMR}\left(150 \mathrm{MHz}, \mathrm{DMSO}-d_{6}\right)$ : $42.5\left(\mathrm{CH}_{2} \mathrm{~N}\right), 60.0\left(\mathrm{CH}_{2} \mathrm{O}\right), 74.5(\mathrm{C}-5), 86.6(\mathrm{C}-3), 115.4(\mathrm{C} \equiv \mathrm{N}), 116.2(\mathrm{C} \equiv \mathrm{N}), 130.6(\mathrm{C}-4), 130.9\left(\mathrm{C}-2^{\prime}, 6^{\prime}\right), 156.6$ (C-3',5'), $158.6\left(C^{\prime} 1^{\prime}\right), 159.1$ (C-6), 162.0 (C-4'), 164.3 (C=O). MS (EI, m/z): 343 (M+2, 1\%), 342 (M+1, 6\%), 341 $\left(\mathrm{M}^{+}, 35 \%\right)$. Anal. calcd. for $\mathrm{C}_{15} \mathrm{H}_{9} \mathrm{FN}_{5} \mathrm{O}_{2} \mathrm{P}$ (341.24): $\mathrm{C}, 52.79 ; \mathrm{H}, 2.65 ; \mathrm{N}, 20.52 \%$. Found: $\mathrm{C}, 52.43 ; \mathrm{H}, 2.36 ; \mathrm{N}$, $20.19 \%$.

Synthesis of 2-ethoxy-8-(4-fluorophenyl)-3-methyl-2-oxido-6-oxo-1,3,4,6-tetrahydro-2H-pyrido[1,2-b] $[1,2,4,5]$ triazaphosphinine-7,9-dicarbonitrile (16). A mixture of compound $1(0.675 \mathrm{~g}, 2.5 \mathrm{mmol})$ and acetaldehyde $(0.132 \mathrm{~g}, 3 \mathrm{mmol})$ was warmed for 2 hour at $35-40{ }^{\circ} \mathrm{C}$, then added diethyl phosphite $(0.4 \mathrm{ml}$, $2.85 \mathrm{mmol}$ ) and two drops of trifluoroboron etherate. The reaction mixture was heated under reflux on water bath for 10 hours. The reaction mixture was treated with ethyl acetate, giving crude solid which was crystallized from diluted ethanol to give pale yellow solid in $35 \%$ yield $(0.34 \mathrm{~g})$; mp $252-254{ }^{\circ} \mathrm{C}$. IR $(\mathrm{KBr}),\left(v_{\max }\right.$,

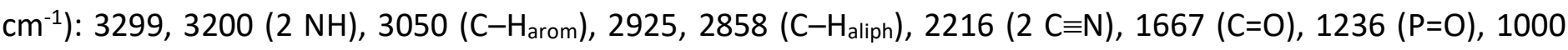
(P-O-C). ${ }^{1} \mathrm{H}-N M R\left(400 \mathrm{MHz}, \mathrm{DMSO}-\mathrm{d}_{6}\right): 1.24$ (t, 3H, J $\left.7.2 \mathrm{~Hz}, \mathrm{CH}_{3}\right), 1.85$ (d, 3H, J $\left.2.5 \mathrm{~Hz}, \mathrm{CH}_{3}\right), 3.97$ (q, $2 \mathrm{H}, J 7.2$ $\mathrm{Hz}, \mathrm{CH}_{2}$ ), 4.50 (q, 1H, J $\left.18.6 \mathrm{~Hz}, \mathrm{P}-\mathrm{CH}\right), 7.45$ (d, 2H, J $\left.9.8 \mathrm{~Hz}, \mathrm{Ar}-\mathrm{H}\right), 7.70$ (d, 2H, J $\left.11.2 \mathrm{~Hz}, \mathrm{Ar}-\mathrm{H}\right), 7.80$ (s, $1 \mathrm{H}$, $\mathrm{NH}), 10.06(\mathrm{~s}, 1 \mathrm{H}, \mathrm{NH}) .{ }^{13} \mathrm{C}-\mathrm{NMR}\left(100 \mathrm{MHz}, \mathrm{DMSO}-d_{6}\right): 15.9\left(\mathrm{CH}_{3}\right), 35.0\left(\mathrm{CH}_{3}\right), 53.5(\mathrm{~d}, \mathrm{~J}=150 \mathrm{~Hz}, \mathrm{P}-\mathrm{CH}), 63.0$ $\left(\mathrm{CH}_{2}\right), 75.8(\mathrm{C}-5), 85.1(\mathrm{C}-3), 110.9(\mathrm{C} \equiv \mathrm{N}), 112.0(\mathrm{C} \equiv \mathrm{N}), 133.5(\mathrm{C}-4), 134.0,134.7\left(\mathrm{C}-2^{\prime}, 6^{\prime}\right), 155.6\left(\mathrm{C}-3^{\prime}, 5^{\prime}\right)$, $158.1\left(\mathrm{C}-1^{\prime}\right), 159.3(\mathrm{C}-6), 162.2\left(\mathrm{C}-4^{\prime}\right), 167.3(\mathrm{C}=0) .{ }^{31} \mathrm{P}-\mathrm{NMR}\left(242 \mathrm{MHz}, \quad \mathrm{DMSO}-d_{6}\right): 22.2 \mathrm{ppm} . \mathrm{MS}(\mathrm{El}, \mathrm{m} / \mathrm{z})$ : $387\left(\mathrm{M}^{+}, 8 \%\right)$. Anal. calcd. for $\mathrm{C}_{17} \mathrm{H}_{15} \mathrm{FN}_{5} \mathrm{O}_{3} \mathrm{P}$ (387.30): C, 52.72; $\mathrm{H}, 3.90 ; \mathrm{N}, 18.08$. Found: $\mathrm{C}, 52.39 ; \mathrm{H}, 3.63 ; \mathrm{N}$, $17.84 \%$.

Synthesis of 8-(4-fluorophenyl)-3-methyl-2-oxido-6-oxo-2-phenyl-1,3,4,6-tetrahydro-2H-pyrido[1,2-b] $[1,2,4,5]$ triazaphosphinine-7,9-dicarbonitrile (19). A mixture of compound 1 (0.675 g, $2.5 \mathrm{mmol})$ and acetaldehyde $(0.132 \mathrm{~g}, 3 \mathrm{mmol})$ was warmed for 2 hour at $35-40{ }^{\circ} \mathrm{C}$, then added $P, P$-dichlorophenylphosphine $(0.34 \mathrm{ml}, 2.5 \mathrm{mmol})$ and heated under reflux on water bath for 10 hours. The reaction mixture was treated with cold water, giving crude solid which was crystallized from diluted ethanol to give pale yellow solid in $45 \%$

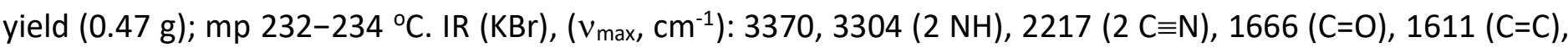
$1237(\mathrm{P}=\mathrm{O}) .{ }^{1} \mathrm{H}-\mathrm{NMR}(400 \mathrm{MHz}$, DMSO-d 6$): 2.08$ (d, 3H, J $\left.2.4 \mathrm{~Hz}, \mathrm{CH}_{3}\right), 4.14-4.20(\mathrm{~m}, 1 \mathrm{H}, \mathrm{P}-\mathrm{CH}), 6.92$ (dd, $1 \mathrm{H}, J$ 8.4 and $4.2 \mathrm{~Hz}, \mathrm{Ph}-\mathrm{H}), 7.18-7.26(\mathrm{~m}, 4 \mathrm{H}, \mathrm{Ar}-\mathrm{H}$ and $\mathrm{Ph}-\mathrm{H}), 7.40-7.41(\mathrm{~m}, 3 \mathrm{H}, \mathrm{Ar}-\mathrm{H}$ and $\mathrm{Ph}-\mathrm{H}), 7.50(\mathrm{dd}, 1 \mathrm{H}, J$ 7.8 and $2.4 \mathrm{~Hz}, \mathrm{Ph}-\mathrm{H}), 8.79(\mathrm{~s}, 1 \mathrm{H}, \mathrm{NH}), 9.15(\mathrm{~s}, 1 \mathrm{H}, \mathrm{NH}) .{ }^{13} \mathrm{C}-\mathrm{NMR}\left(100 \mathrm{MHz}, \mathrm{DMSO}-d_{6}\right): 34.4\left(\mathrm{CH}_{3}\right), 45.5(\mathrm{~d}, J$ $138 \mathrm{~Hz}, \mathrm{P}-\mathrm{CH}), 75.0(\mathrm{C}-5), 82.0(\mathrm{C}-3), 116.2(\mathrm{C} \equiv \mathrm{N}), 116.4(\mathrm{C} \equiv \mathrm{N}), 120.3\left(\mathrm{C}-3^{\prime \prime}, 5^{\prime \prime}\right), 127.6,127.8\left(\mathrm{C}-2^{\prime \prime}, 6^{\prime \prime}\right)$,

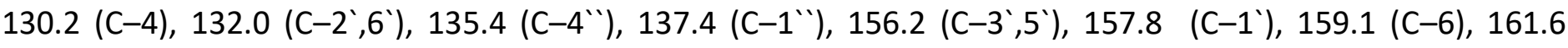


(C-4 $\left.{ }^{\prime}\right), 167.5$ (C=O). MS (El, $\left.m / z\right): 419\left(\mathrm{M}^{+}, 8 \%\right.$ ). Anal. calcd. for $\mathrm{C}_{21} \mathrm{H}_{15} \mathrm{FN}_{5} \mathrm{O}_{2} \mathrm{P}$ (419.34): C, 60.15; $\mathrm{H}, 3.61 ; \mathrm{N}$, $16.70 \%$. Found: C, 59.82; H, 3.29; N, 16.34\%.

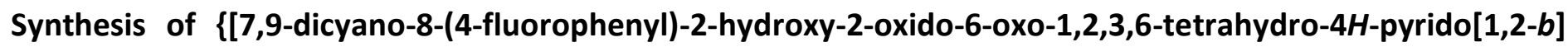
$[1,2,4,5]$ triazaphosphinine-4-yl]methyl\}phosphonic acid (22). A solution of phosphorous acid $(0.41 \mathrm{~g}, 5 \mathrm{mmol})$ in distilled water $(5 \mathrm{ml})$ was added dropwise to an acidic solution of compound 1 ( $0.67 \mathrm{~g}, 5 \mathrm{mmol})$ in diluted hydrochloric acid $(30 \mathrm{ml}, 5 \%)$ in presence of formaldehyde $(1 \mathrm{ml})$. The mixture was heated under reflux for 10 hours. The solvent was evaporated. After adding some cold water, the formed solid was filtered off and crystallized from diluted DMF to give yellow solid in $55 \%$ yield $(0.56 \mathrm{~g}) ; \mathrm{mp} 259-260{ }^{\circ} \mathrm{C}$. IR $(\mathrm{KBr}),\left(V_{\max }, \mathrm{cm}^{-1}\right)$ :

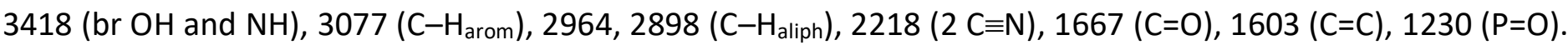
${ }^{1} \mathrm{H}-\mathrm{NMR}\left(400 \mathrm{MHz}, \mathrm{DMSO}-\mathrm{d}_{6}\right): 4.54-5.15\left(\mathrm{~m}, 4 \mathrm{H}, 2 \mathrm{P}-\mathrm{CH}_{2}\right), 3.68(\mathrm{br}, 3 \mathrm{H}, \mathrm{P}-\mathrm{OH}), 7.43$ (td, $2 \mathrm{H}, J 8.8$ and $2.4 \mathrm{~Hz}$, $\mathrm{Ar}-\mathrm{H}$ ), 7.58 (td, $2 \mathrm{H}, J 9.2$ and $4.0 \mathrm{~Hz}, \mathrm{Ar}-\mathrm{H}), 10.34(\mathrm{~s}, 1 \mathrm{H}, \mathrm{NH}) .{ }^{13} \mathrm{C}-\mathrm{NMR}\left(100 \mathrm{MHz}, \mathrm{DMSO}-d_{6}\right): 45.0\left(\mathrm{P}-\mathrm{CH}_{2}\right)$, $50.5\left(\mathrm{P}-\mathrm{CH}_{2}\right), 76.3(\mathrm{C}-5), 90.4(\mathrm{C}-3), 114.8(\mathrm{C} \equiv \mathrm{N}), 115.8(\mathrm{C} \equiv \mathrm{N}), 130.5(\mathrm{C}-4), 130.6\left(\mathrm{C}-2^{\prime}, 6^{\prime}\right), 154.4\left(\mathrm{C}-3^{\prime}, 5^{\prime}\right)$, $154.8\left(C-1^{\prime}\right), 159.7(C-6), 161.9$ (C-4'), 164.4 (C=0). ${ }^{31} \mathrm{P}-\mathrm{NMR}\left(242 \mathrm{MHz}, \mathrm{DMSO}-d_{6}\right): 11.7$ and 19.2 ppm. MS (EI, $m / z): 409(\mathrm{M}+1,6 \%), 408\left(\mathrm{M}^{+}, 32 \%\right)$. Anal. calcd. for $\mathrm{C}_{15} \mathrm{H}_{12} \mathrm{FN}_{5} \mathrm{O}_{6} \mathrm{P}$ (408.26): $\mathrm{C}, 44.13 ; \mathrm{H}, 2.96 ; \mathrm{N}, 17.15 \%$. Found: $\mathrm{C}, 43.61 ; \mathrm{H}, 2.61 ; \mathrm{N}, 16.83 \%$.

\section{Acknowledgements}

The authors extend their appreciation to the Deanship of Scientific Research at King Khalid University for funding this work through research groups program under grant number R.G.P.1/22/38.

\section{References}

1. Holla, B. S.; Ashok, M. Phosphorus, Sulfur Silicon Relat. Elem. 2007, 182, 981.

https://doi.org/10.1080/10426500601088853

2. Eugenia, F. C.; Laichici, M.; Gheorghe, F. C.; Vlascici, D. J. Serb. Chem. Soc. 2006, 71, 1031. https://doi.org/10.2298/JSC0610031F

3. He, L. N.; Zhuo, R. X.; Chen, R.Y.; Li, K.; Zhang, Y. J. Heteroat. Chem. 1999, 10, 105. https://doi.org/10.1002/(SICI)1098-1071(1999)10:2<105::AID-HC3>3.0.CO;2-V

4. Ali, T. E. Eur. J. Med. Chem. 2009, 44, 4539. https://doi.org/10.1016/j.ejmech.2009.06.022

5. Abdou, W. M.; Ganoub, N. A.; Sabry, E. Monatsh Chem. 2016, 147, 619. https://doi.org/10.1007/s00706-015-1542-4

6. Chen, R. Y.; Mao, L. J. ; Chen, X. Phosphorus, Sulfur Silicon Relat. Elem. 2000, 165, 91. https://doi.org/10.1080/10426500008076328

7. Chen, R. Y.; Mao, L. J. Heteroat. Chem. 1994, 5, 125. https://doi.org/10.1002/hc.520050208

8. Chen, R. Y.; Mao, L. J.; Chen, X. Phosphorus, Sulfur Silicon Relat. Elem. 1994, 89, 83. https://doi.org/10.1080/10426509408020436

9. Boger, D. L.; Nakahara, S. J. Org. Chem. 1991, 56, 880.

https://doi.org/10.1021/jo00002a077

10. Reddy, T. R. K.; Mutter, R.; Heal, W.; Guo, K.; Gillet, V. J.; Pratt, S.; Chen, B. J. Med. Chem. 2006, $49,607$. 
https://doi.org/10.1021/jm050610f

11. Manna, F.; Chimenti, F.; Bolasco, A.; Filippelli, A.; Palla, A.; Filippelli, W.; Lampa, E.; Mercantini, R. Eur. J. Med. Chem. 1992, 27, 627.

https://doi.org/10.1016/0223-5234(92)90141-M

12. El-Hawash, S. M.; Abdel Wahab, A. E.; El-Demellawy, M. A. Arch. Pharm. 2006, 339, 14. https://doi.org/10.1002/ardp.200500161

13. Samadi, A.; Marco-Contelles, J ; Soriano, E.; Alvarez-Perez, M.; Chioua, M.; Romero, A.; Gonzalez-Lafuente, L.; Gandia, L.; Roda, J. M.; Lopez, M. G.; Villarroya, M.; Garcia, A.G.; Rios, C. D. L. Bioorg. Med. Chem. 2010, $18,5861$.

https://doi.org/10.1016/j.bmc.2010.06.095

14. Cocco, M. T.; Congiu, C.; Lilliu, V.; Onnis, V. Bioorg. Med. Chem. 2007, 15, 1859.

https://doi.org/10.1016/j.bmc.2006.11.031

15. Behbehani, H.; Ibrahim, H. M.; Makhseed, S.; Elnagdi, M. H.; Mahmoud, H. Eur. J. Med. Chem. 2012, 52, 51. https://doi.org/10.1016/j.ejmech.2012.03.004

16. Begue, J. P.; Delpon, D. B. J. Fluorine Chem. 2006, 127, 992.

https://doi.org/10.1016/j.jfluchem.2006.05.006

17. Ismail, F. M. D. J. Fluorine Chem. 2002, 118, 27.

https://doi.org/10.1016/S0022-1139(02)00201-4

18. Ali, T. E.; El-Edfawy, S. M. Res. Chem. Intermed. 2016, 42, 1329.

https://doi.org/10.1007/s11164-015-2088-0

19. Ali, T. E.; Ibrahim, M. A.; El-Edfawy, S. M. Phosphorus, Sulfur Silicon Relat. Elem. 2017, 192, 819.

https://doi.org/10.1080/10426507.2017.1287183

20. Abdel-kariem, S. M.; Ali, T. E. J. Heterocycl. Chem. 2017, 54, 2916.

https://doi.org/10.1002/jhet.2902

21. Al-Najjar, A. A.; Amer, S. A.; Raid, M.; Elghamry, I.; Elnagdi, M. H. J. Chem. Res. 1996, 296.

22. Yang H.; and Lu, R. Synth. Commun. 1994, 24, 59.

https://doi.org/10.1080/00397919408012626

23. Prasad, G. S.; Babu, B. H.; Reddy, C. D.; Raju, C. N.; Reddy C. S. Synthet. Commun. 2008, $38,85$. https://doi.org/10.1080/00397910701649148

24. Ali, T. E. Phosphorus, Sulfur Silicon Relat. Elem. 2010, 185, 88. https://doi.org/10.1080/10426500802713309

25. Ali, T. E. Arkivoc 2014, 21.

26. Beck, J.; Gharbi, S.; Herteg-Fernea, A.; Vercheval, L.; Bebrone, C.; Lassaux, P.; Zervosen, A.; MarchandBrynaert, J. Eur. J. Org. Chem. 2009, 85.

27. Octaviano, J. Z.; Martinez, A. H.; Guevara, A. O.; Elizalde, I. L.; Hopfl, H. Heteroat. Chem. 2006, $17,75$. https://doi.org/10.1002/hc.20178

28. Wang, B.; Miao, Z. W.; Haung, Y.; Chen, R. Y. Heterocycles 2006, 68, 2123. https://doi.org/10.3987/COM-06-10838

29. Aime, S.; Cavallotti, C.; Gianolio, E.; Giovenzana, G. B.; Palmisano, G.; Sisti, M. Tetrahedron 2002, $43,8387$. https://doi.org/10.1016/S0040-4039(02)01950-0

30. Vuano, B. M.; Acebal, S. G.; Sala, O.; Brieux, O.; Pieroni, O. I. J. Mol. Struct. 2004, 690, 77. 